lished, Mr. Morse offered it to the government for $\$ 100,000$. Upon adverse representations made by the Postmaster-Genenlist private capital in the development of his invention
It was not an easy task. Men with money fought shy of the new undertaking. To stir the capitalists up, a short experimental line was laid in New York city from No. 112 Broad-
way to a house near the Metropolitan $\mathrm{H}_{0}$ tel. It was with way to a house near the Metropolitan Hotel. It was with
the utmost difficulty that permission was obtained to have the connecting wires strung along the tops of the bouses, the owners fearing an increase of liability of their property being struck by lightning. Mr. Ezra Cornell, afterward the
founder of Cornell University, had cbarge of this experiment. Fifteen thousend dollar's were needed to construct a
line from Fort Lee to Philadel phia, which was the first link line from Fort Lee to Philadelphia, which was the first link
of a projected line to $W$ aslington via Baltimore. This of a projected line to Waslington via Baltimore. This
money was subscribed, Mr. Corcoran, of Washington, being the United States was granted by the Maryland Legislature. The first company was known as the "Magnetic Telegrap
Company."-Electrical Era.

\section{LIGHTNING CONDUCTORS.*} THE testing of lightning conductors slould comprise-(1) The eartl.s
The testing of the conductivity of the conductor, which should bave a very low electrical resistance, is very delicate, other reasins, the section of the conductor is red uced in some parts to very small dimensions, while the electricil tests show
no appreciable diminution of conductivity. It is certain he Con ris des Electriciens, that the continuity of a conductor might be completely interrupted at one point without destroying the efficiency of the conductor as a preservative against lightning, while a fine wire connecting two distant
parts of the principal conductor migltt present a perfect conparts of the principal conductor might present a perfect conspberic electricity of a storm.
In any case there is no doubt that it is indispensable that the branches of a lightning conductor and their continuity be tested with care from time to time, as is done annually with the lightning conductors on military edifices. As for
the frequent trials of continuity, these mily be easily made the frequent trials of continuity, these mily be easily made
by means of a battery and galvanometer, as will be shown

The good communication with the earth, which is at least two other earth wires, completely independent of the first and embedded in the soil at a distance sufficient to give perfect diffusion of the electric fluid at each point, and to prevent the passage of electricity directly through the earth
which separates them. By means of three galvanometrical experiments we may have the sum of the resistances of these communications taken two by two, and deduce from it the value of each. If $x, y$, and $z$ represent these resistances, $a, b$, and $c$ the values found for the sums $x+y, x+z$, and $y+z$,
we have:

$$
x=\frac{a+b-c}{2}, y=\frac{a+c-b}{2}, z=\frac{b+c-a}{2} .
$$

This experiment, which is very delicate, and in which we evidently cannot be iutrusted to inexperienced persons. For the lightning conductors of Paris, for example, it is
Fon generally considered sufficient to plant in the earth, at a slort distance from the ligltning conductor, a metallic plate,
with a surface one decimeter square, and to ascertain that with a surface one decimeter square, and to ascertain that
the current passes when this plate is connected with the rod by introducing into the circuit a battery and a galvanometer. very high; it often exceeds, it appears, 2 to $300 \mathrm{ohms}$, which is a very considerable tigure, if we consider that in
telegraph offices the resistance opposed to the current by the telegraph offices the resistance opposed to the current by the 20 or 25 ohms. It seems necessary to fix a maximum for the resistance which we ought to take for the communic capable of being fixed at $250 \mathrm{olm}$; and when we determine the total resistance by taking two independent earth wires, we should not obtain a figure higher than 5 ohms.
For the measurement of this resistance the method which seems most simple and most practicable is that by a differenThe committee propnses, therefore, to establish in a fixed
Thal position in every building provided with a lightning rod, $i$ addition to the principal eartl contact, a second contact, completely independent of the first, and situated at 20,30 , or more meters frnm it, accoril be tested as to perfect efficiency. once for all, by a competent person. This second contact room and may morever be uttached to the principal con ductor when not required for making tests. principal conA wire covered with gutta percha would be carried off from an elevated part, A. of the lightning rod, and would lead to an interrupter, $C$, insulated in the normal state. This interrupter would allow of connecting at will, by means
of a metallic pluy, the lightning rod, A, B, with one of the circuits of a differential galvanometer, G. The other exrupter, $Q$, in connection with a small battery, $P$, and with the second earth wire, $\mathbf{S}$.
The secind circuit of the differential galvanometer would be connected, on one hand, with the ineerrupter, $Q$, and on
the other, at the point, $H$, with the auxiliary earth wire, $H$, the other, at the point, $\mathrm{H}$, with the auxiliary earth wire, $\mathrm{H}$,
$\mathrm{S}$; a resistance, $\mathrm{R}$, equal to that which should not be exceeded by the eartith conneclinn between $\mathrm{H}$ and $\mathrm{T}$, or about 50 To make the test, we would commence by closing the local circuit, by putting in the plug of the interrupter, $Q$, which
would enable us to ascertain, by tise deflection of the needle, whether the battery, P, is in good condition; then we should put in the plug of the second interrupter, C. The galvano-
meter needle sloould return to a state of repose, or even pass lower than the resistance. $R$, or $50 \mathrm{obms}$, that is to tion should not change in direction, it should be ascertained whether the conductivity of the portion of the rod, A, B, is interrupted, or whether the connections with the earth are
defective, which would be the case if, for instance, one of them being formed of a plate, originally immersed in water, had become dry.

*Annales Telegraphiques. - Extract Prom a Report of the Committee of
Improvement of the l'ostai and Telegraphic Administration.-Electrical
S.eview.
This examination should be intrusted to an experienced
man, who sfould be warned by the attendant of the bad man, who should be warned by the attendant of the bad
state of the connections; but the experiment could easily be carried further. It would be sufficient to have a second ire, L, B, establisbing communication between the com-
utator, C, and the toot of the lightning, rod, in which would be placed an interrupter, I, and to connect this wire
with the point, $\mathrm{H}$, by a conductor also provided wlth an inwith the point, $\mathrm{H}$, by a conductor also provided wlth an in-
terrupter, $\mathrm{K}$. In the normal condition the circuit would be closed by
the plug of the interrupter, I, which would furuish a second connection, A, I, T, between the sumnit of the rod and the earth; to make the first trial, as was indicated above, it would
suffice to remove the plug of the interrupter, I, and proceed as before. In order to insure the continuity of the ligbtning conductor, metallic plugs should be inserted in the three in-
terrupters, K, C, and Q; the two circuits of the differential galvanometer being closed, the needle should remain at rest the rod, if the resistance of the circuit, H, N, K. B. A, L, $\mathrm{C}$, is below that of the rhenstat, $\mathrm{R}$. A resistance slightly
below $\mathbf{R}$, pliced at $\mathbf{N}$, would render this test still more exact, and would enable us to make sure that the rod of the lightning couductor and the auxillary wires onler only an insignificant resistance, and are consequently in good con-
dition. If it were found that the current. which ought to pass through the lightning conductor does not do so, the fault could be discovered by arranging a conducting wire i communication, on the one land, with the interrupter, $K$, the other extremity being connected with various points of
the lightning conductor between $B$ and $A$.

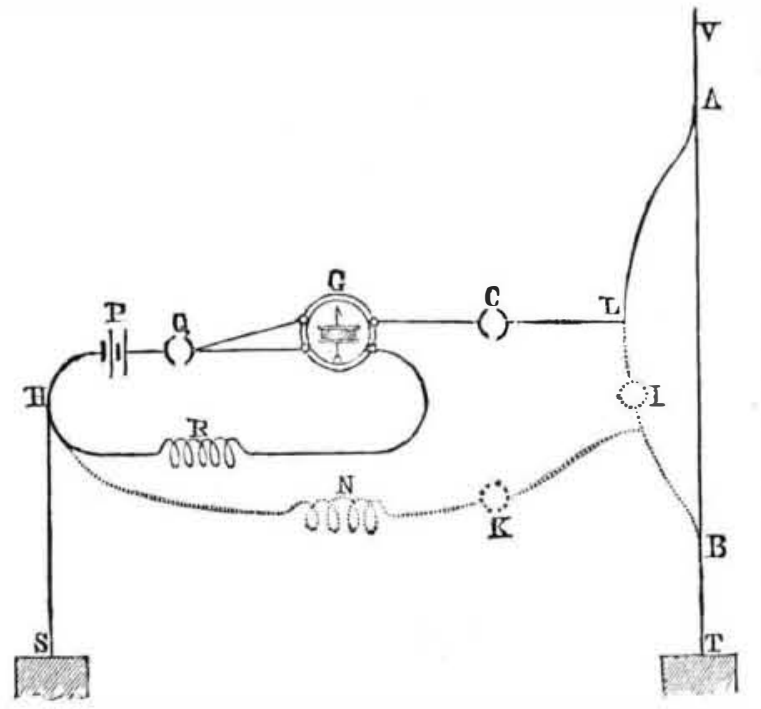

Lastly, if the principal conductor should be found br ex-
periment to be in good condition, the secondary wire periment to be in gond condition, the secondary wire, H,
should be tested as well, and also the communication with the earth. These tests present no difficulty, and require no complicated instrument, il order to obtain accuracy. The
galvanometer may bave the ordinary form of the galvanometers at telegraph stations; and as to the battery, it may We have indicated 50 ohms as the limit of resist

We have indicated 50 ohms as the limit of resistalice bevisable, in each particular case, to examine whether this visable, in each particular case, to examine whether this
limit is sufficient, or if it would not be better to fix a some-
what different value. This value slould depend on the mure or less advantageous installation of the eart $\mathrm{l}$ wires.

In order to avoid all danger, it is better that the commu-
tators $\mathrm{C}$ and $\mathrm{K}$, which should be in readiness in the experimenting room, should have, on ordinary occasions, no communication with the lightning conductor, which might be
effected by detaching the wires connecting them with the conductor, A, I, B, if the latter be external, or by cutting
off, at $\mathbf{A}$ and B, the communication of the wire, A, I, B, off, at $\mathbf{A}$ and $\mathbf{B}$, the communication of the wire, A, I, B,
with the lightning conductor. When there is telegraphic communication with a station situated at a certain distance, the estallishment of a second earth wire, $\mathrm{H}$, $\mathrm{S}$, is useless.
It is sufficient to connect the point, $\mathrm{H}$, w it h the telegraph wire itself, placed directly in communication with the earth at its other extremity at the time of the experiment; but then AN APPLICATION OF ELECTRICITY TO SUR-

WE borrow from one of the last numbers of the Elektrotechnische Rundschau a description of an apparatus conwill prove an advantageous substitute for the apparatus that
have bitherto been employed in resections and tepanning. have litherto been employed in resections and tepanning. Resection is an operation that consists in removing an affect-
ed part of a bone. In this operation the surgeon holds the decayed parts with one hand and uses the surgical saw with The operation is not of the easiest character, and always virom the 'Third Annual Report of the State Board of Health of West

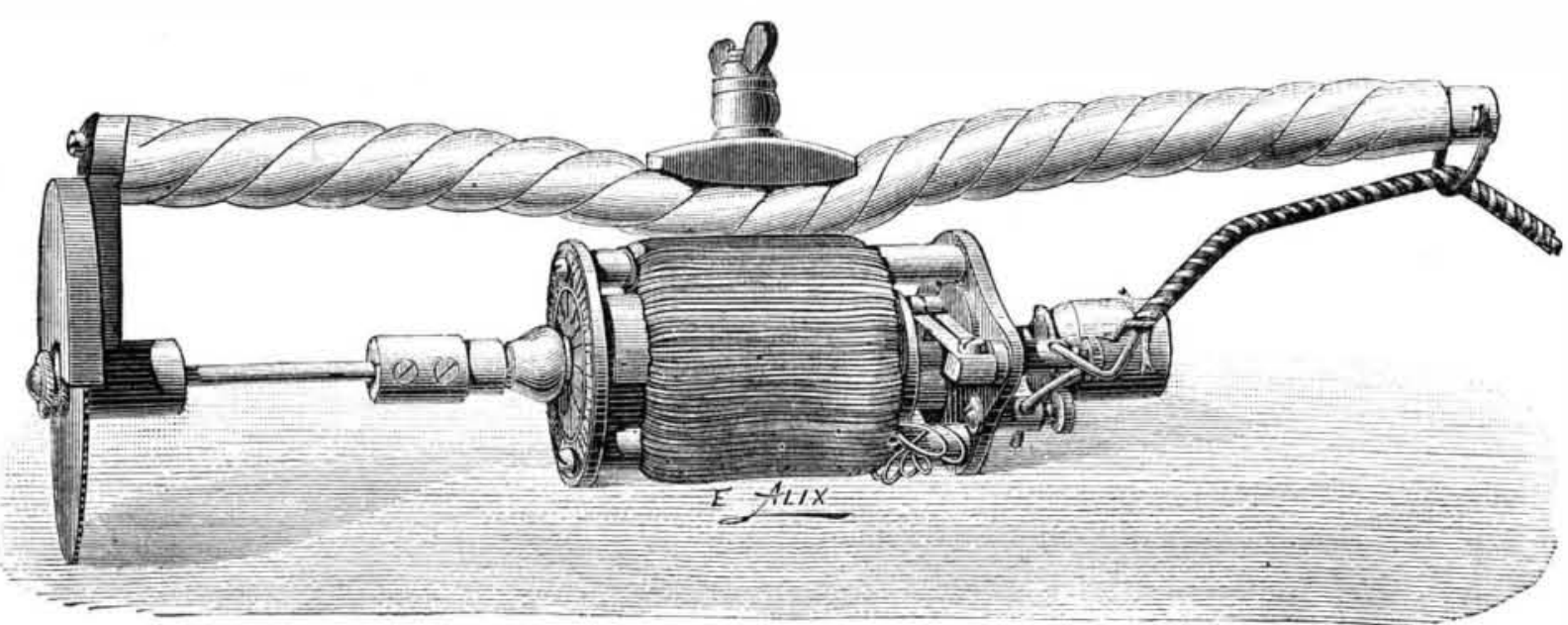

SURGICAL ELECTRICITY

strength, as may easily be imagined. The apparatus shown
Thenglar of force for muscular, so that the whole attention of the operator may be devoted to the delicate parts of the operTho instrument consists essentially of a metallic liandle, to the center of which is screwed a small Griscom electric mounted a circular saw. The upper half of the latter moves placed in any position whatever, without the cperaior's runninis an
of the saw

The apparatus is equally well adapted for trepanning, the
ircular saw in this case being merely replaced by a trepan The electromotive force necessary may be obtained by ments made by Dr. Th. Stein are of the most satisfactory nature, both as regards the accuracy and the rapidity with found that with this instrument the very largest bones may be sawed through in thirty seconds, a result that could not possibly be obtained with the best instruments and most
skillful hand hy ordinary processes. - La Lumiere Electrique.

THE RELATIONS OF THE SOIL TO HEALTH.* By George H. Rohe, M.D. I. 一THE SOIL.

THat wisest and most learned of the ancients, Hippocrates, called the Father of Medicine, treated at length in one of his works of the sanitary influence of the soil. Others. of the
older writers, especially Herodotus and Galen, called attenRoman architect, who flourished about the beginning of the Christian era, taugltt that a point of first importance in building a dwelling was to select a site upon a healtby soil.
From this time until the beginning of the eigliteentls century, very little of value is found in medical literature bearhis great work on the causes of malarial fevers, in which he pointed out of the relations existing between marshes and low. lying lands and those diseases. by common consent,
called malarial. Other authors of the eighteentl and the early part of the nineteenth century refer to the connection
between the snil and disease, but exact investigations lave only been made within the last thirty years. The general
want of definite knowledge upon this subject, even among well-educated people, is the occasion of the following When we consider that the air wo breatbe, and much of the water we driuk, are influenced in their composition by the matters in the soil, the great importance of possessing a
thorough knowledge of the physical and chemical conditions of the soil becomes evident to every one.
In the hygienic, as in the geological sense, we include rock, The suil, as it is presented to us ait the surface of the earth, is
The and The suil, as it is presented to us at the surface of the earth, is
the result of long ages of disintegration of the primitive rocks by the action of tue elements, of the decomposition of organic principal factor, lowever, is the action of water upon rock ny leveling the projections of the earth's surface, produced
by volcanic action. Soils vary considerably in physical and chemical constituof we may have, for example, a soil consisting exclusive ther soils may consist of a mixture of two or more of these In forests, we find a layer of this slowly decomposing vegetable maiter of varying thickness covering the eartly

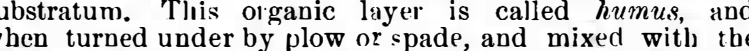
or clay-base, it constitutes the ordinary agricultural II.-THE ATMOSPHERE OF THE SOIL, OR GROUND AIR. The interstices of the soil are occupied by air or water, or yd hotl together. The suil's atmosphere is continuous with which envelops the earth. Its proportion to the mass of the soil depends upon the degree of porosity of the soil and upon the amount of moisture present. In a very porous soil,
such as for example a coarse sand, gravelly loan, or coarse grained sindstone, the amount of air is mucb greater when the soil contains a large proportion of water, the air is to llis extent excluded. The porosity of various soils, as greater than would, at first thought, be supposed. 'Thus it has been frund that porous silldstone may contain as far contained in sand, gravel, or loose soil may amount to thirty to fifty per cent.

The which bad various chemical decompositions going on there. In

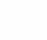


\begin{tabular}{l|l} 
consequence of these clemical changes, the relative propor- & mosphere approaching in impurity that just mentioned. It \\
tions of the oxygen and carbonic acid in the air are changed, & requires no very vivid imagiuation to appreciate the dangers
\end{tabular} tions of the oxygen and carbonic acid in the air are cbanged, well known that, during the decay of vegetable matter in the air, carbonic acid is formed; one constituent of this compound-the carbon- being derived from the vegetable mat-
ter while the oxgen is taken from the air. Hence, if this action takesplace where there is not a very free circulation mal proportion of oxygen, which enters into combination with the carbon of the vegetable matter to form carbonic Thirty years ago, MM Boussingault and Levy, two distin-
guished Frencb chemists, examined the air contained in ordi nary agriculturalsoil, and found that the oxygen was diminished to about one-half of the proportion nominally present in atmospheric air, while the carbonic acid was enormously
increased. The exict results obtained by Boussingault and In one hundred volumes of ground air there were 10.35 volumes of oxygen, 79.91 volumes of nitrogen, 974 volumes
of carbonic acid. In atmospheric air, on the other band, there are in one bundred volumes 20.9 volumes of oxygen, $79 \cdot 1$ volumes of nitrogen, 0.04 volume of carbonic acid,
a bout one twenty-fiftl of one per cent. of carbonic acid. In spite of the striking results obtained by these two chem
and ists, very little ittention was paid to them by sanitarians, existing between the motions of the air above ground and that under ground.
In 1871, however, Prof. Von Pcttenkofer, of Munich whose authority in sanitary matters is second to none, pub-
lished the results of bis own examinations into tbe constitution and physical conditions of the ground air, and the relaThese researches, wbich created a widespread interest in the subject, were extended by other observers in all parts of the world. These observers, prominent among whom we
Professors Fleck and Fodor in Germany, Drs. Lewis a Cunningbam in India, Prof. W $m$. Ripley Nichols in Bns
ton, and Surgeons J. H. Kidder and S. H. Griffith, of the U.
S. Navy, in Washington, demonstrated that the increase S. Navy, in Washington, demonstrated that the increase of
carbonic acid in the ground air is due to increased vegetable caronic acid in the ground air is due to increased vegetiable
permeable, that is to lessened permeability of the soil. A
perandy or gravelly soil, is likely to contain less carbonic acid in its atmosplere than a dense, going on, and the production of carbonic acid in the former going on, and the production of carbonic acid in the former, acid may easily escape and be diffused in the superincumbent air, while the close-pored clay imprisons the carbonic
acid and prevents or retards its escape into the air above. The disappearance of oxysen from the ground atmosphere carbonic acid. It appears from this that in the soil an oxiwhich is the excess of carbonic acid in the ground air. Prof. Nichols has found the proportion of carbunic acid in the air taken from a depth of ten feet below the surface in the observation being made in August. In December, at a Fodor, in Buda-Pestb, fuund the proportion of carbonic acid taken from a depth of thirteen feet.
Movements of the ground atmosphere are principally due Movements of the ground atmosphere are principally due
to differences of pressure and temperature in the air above ground. $O$ wing to sucb differences the air from the soil
frequently permeales houses, entering from cellars or basemore beated (and consequently less dense) than the air out ground air up through the bouse, while the cold external at mosphere penetrates the soil and occupies the place of the displaced ground air.* A similir effect occur's in conse-
quence of beavy rains. The water fills up the interstices of the soil near the surface, and forces the ground air out at
points where the pores remitiv open. These places are the dry ground under buildings, where the air escapes and passes rains may thus be the cause of pollution of the air in bouses.
The greater the porosity of the soil, the more likely is this to happen. This pollution of the bouse air may be prevented
bo having impervious foors and walls to cellars and basements, or by interposing a layer
ground and the floor of the bouse.

In the spring and early summer the ground being colder than the air above it, and the ground air consequently beavbaps due to this fact that those infectious diseases which are
probably dependent upon the movements of the ground air, are less prevalent in the spring and early summer than in the latter part of summer, autumn, and early winter. In the the streets and houses to be inspired by unen and animals. The same conditions may explain the greater likelibood of infection at nigbt, which is provel for such diseases as mala-
rial and yellow fevers. The colder outside air penetrates the interstices of the soil, and forces oul the impure grouud
air. The researches of Fodor bave demonstrated that the proan approximative meisure of the impurity of the soil whence soil, as before pointed out, must bowever not be overlooked in estimating the signification of the carbonic acid. Fodor bas shown that the proportion of carbonic acid in the ground
gic, and consequently the amount of organic decomposition, is greatest in July and least in March. Thit the carbonic
acid is derived from the decomposition of organic matter acid is derived from the decomposition of organic matter
specimens of air brought from the Libyan desert, and found that the proportion of carbonic acid in the ground air was
exactly the same as in the air collected above ground. There exactly the same as in the air collected above ground. There heing no vegetable growth in the desert there can, of
he no vegetable decomposition going on in the soil.

The excess of carbonic acid in the ground air is an indicaair at a depth of thirteen feet below the surface was found to contain only from 7 to 10 per cent. of oxygen-one-half to
one-third of the normal proportion. Many basements occupied by people as living rnoms extend from five to ten feet
underground, and bence are liable to be supplied with an at

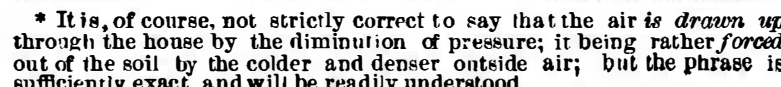

requires no very vivid imagiuation to ap
to bealth that dwell in sucb habitations.

III. -THE WATER OF THE SOIL, OR GROUND WATER.

At a variable depth below the surface of the ground, a
tratum of earth or rock is found through which water pith dificulty, if at all. Above this, there is a and which varies in depth at different a to a lower level, the amount of precipitation (rain or snow-fall) and acwhich it tows. This stratum of water is termed the ground water, and has within the last few years assumed cisusidera-
ble importance from its apparently close relatious to the ble importance from its apparently close relatious to the
spread of certain of the infectious diseases. The direction of horizontal flow of the ground water is always toward the drainage area of the district. Thus, it is usually toward
lakes, rivers, or the sea. Rains or a rise in the river cause a rise iu the ground water, while long continued dry weather, or a low stage of the river, which drains off the ground water,
causes a fall in the latter. On the sea-coast the ground, writer is not aware of any observations made to determine this point. In Minnich, where the ground water flows toward the river Isar, which divides the city it bas been found
that the aunual range or oscillation (the differ'nce between the bighest and lowest level during the year) is ten feet, While the borizontal movement amounts to fifteen feet per
day. In Bulla-Pestl the annual range was found hy Fodor amounts to more than forty feet. As it is from the ground water that the greiter portion of the supply of drinking water in the country and in villages and small towns is prevent, as far as possible, pollution of this source. Cess-
pools and manure heaps and pits, of necessity, contiminate
the soil, and also ground water, for a distance below and around them, and such water is clearly untit for drinking
and and other domestic purposes. Hence, the reason why wells
should not be placed too near privies and manure heaps or Between the level of the ground water, or that portion of he soil where its pores are entirely occupied by the water--
where, in other words, the ground is saturated - and the surface is a stratum of earth more or less moist; that is to say partly with air. It is in this stratum that the processes of organic decay or putrefaction are going on, in consequence
of which the pollution of the ground air occurs. Recent obther vations seem to show that these processes of decomposi-
tion are initiated and kept up by minute organisms, termed nly take place in the presence of the yeast plant. It has n, there are always present multitudes of one variety of
hese minute organisms; while if putrefactive decomposiion is poing on, a different variety of these organisms is pre-
sent. Just as, when a fermenting liquid becomes putrid, the sent. Just as, when a fermenting liquid becomes putrid, the
yeast plant disappears and its place is taken by the ordinary bacteria of putrefaction, so in the soil, if the access of oxy-
gen which is necessary to the life of the bacteria of decay i preveuted, these organisms die and are succeeded by the orgavisms of putrefaction. It bas been found that in a soil
saturated with water the bacteria of decay cannot live, while those of putrefaction may flourish, because these later
organisms can sustain life in the absence of oxygen. Prof. organisms can sustain life in the absence of oxygen. Prof.
Fodor's researches indicate that the organis $m$ of non-putre
factive decomposition or decay is that which is termed by Cohn hacterium lineola; and that the bacterium termo is the IV. -THE DISEASES SPREAD BY SOIL IMPORITIES

Given now an area of soil, say the grouud upon which ceuse or cily is built, with a moist stratum in which the pro-
cesses of decay are active, and imagine a rise in the ground
water. The ground air, charged with carbonic acid and other products of decomposition, is forced out of the pores of the soil by the rising ground water, and escapes into the exter-
nal air, or through cellars and basements into houses, and may there produce disease. But the saturation of the soil
with water prevents the further development of the bacteria of decay, and putrefaction lakes place. If, now, the ground
water sinks to its former level or below, the processes of dequantilies of carbonic acid and other inorganic compounds are produced. If the germs of infectious or contagious disand may escape with the movements of the ground air iuto
and be external atmosphere, and there produce their infective
bu This, it is beld by Pettenkofer and his followers. is what
Ctually occurs in cholera and typhoid fever. Prof. De Chaumont bas laid down the rule that a soil with a persistently low stage of ground water, say 15 feet below the sur-
face of the ground, is bealthy; a persistently high stage of while a fluctuating level of the ground water, esilecially if

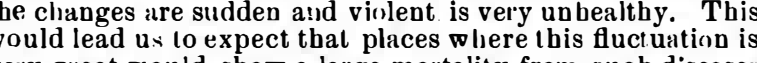
very great would show a large mortality from such diseases
as are attributed to impurities in the soil. And this we find especially true in India. In certain localities in India, cbolera, for example, is cndemic-that is to say, the disease is
never entirely absent in such localities. Calcutta is one of these places. The rainy season begins ahout the first of May
and continues until the end of October. During the next six months there is very little rain. It is fair to assume that the
ground water rises during the rainy season, and checks decaly aud the multiplication of the germs of the disease in the sol, and that these processes become more active as the dry
season advances and the ground water level falls. If we
note the death rate from cholera in Calcutta it will be found that it bears a distinct relation to the movement of the from October, and reach their beight in April. Dr. Mac-
pherson, who bas written a very elaborate bistory of Asiatic cholera, shows this relation very clearly. For twenty-six from November to April. The average number of death from cholera aunually was 4,013. Ot inese, 1,238 died in the the period of dry weat her:
In the cholera epidemics of 1866 and 1873 in Buda-Pesth, the same relations existed between the ground water and the
cholera. As the level of the ground water rose. the cholera cholera. As the level of the ground water rose. the cholera
diminisbed, while the disease iucreased upon the sinking of the ground water. Exactly the same
by the disease io Mudich in 1873. bacteria, just as fermentation in liquids containing sugar can
There seems good reason to believe that typhoid fever is propagated in consequeuce of movements of the ground wa does not exclude the infection of drinking waler by the disease germ, since much of the drinking water used, as before
tated, is drawn from the ground water. Peltenkofer, Bubl stated, is drawn from the ground water. Pettenkofer, Bubl,
and Virchow bave shown that the death rate from typloid
fever bas a distinct and definite relation to the ground wafever has a distinct and definite relation to the ground $\pi \mathrm{a}-$
ter oscillations. This has been incontestably prover for two cities, Munich and Berlin. When the level of the ground water is above the average. typhoid fever decreases;
when it is below the average, the number of cases becomes Facts at present on record indicate that the stage of the round water bis an unquestionable relation to the sickness
ate from intermittent fever. Malarial fevers are generally marshy regions, and so they usually are. But it is a note-
more nor most virulent when the swamps are full. It is in the at ter part of summer and early autumn, when the water is being gradually evaporated, and the swampy soil is drying that the fevers begin. In the winter and spring. when the ground becomes satur ated to the surface from the abundint
precipitation, and the processes of decomposition are checked, precipitation, and the processes of decomposition are checked,
the fever disappears or, at all events, the cases decrease in About twenty years ago Dr. Henry I. Bowditcb, of Bos-
aber on, called attention to the frequent connection between ases of pulmonary consumption and dampness of the soi
ubon which the patients lived. After a very extended and
aborious investigation, Dr. Bowditch formulated these two "First--A residence in or near a damp soil, whether that dampness be inberent in the soil itself or caused by percolais one of the principal causes of consumplion in Massacbu-
setts, probably in New England, and possibly cther portion setts, probably in New England, and possibly cther portion
of the globe. possibly-nay, probably-prevented in some instances by Dr. Buchanan, of England, about the same time showed
hat the thorough drainage of certain English cities bad markedly diminished the deatbs from consumption in the drained cities. So far as the writer is aware, not a single
fact has been established which militates against the law laid down by Dr. Bowditch and as strongly supported by notice has been taken of these resulis by pbysicians. Few practical use of such knowledge in advising patients. As
corroborative of the views of Dr. Bowditch, the rarity of consumption in bigh

7. DISEASES OF ANIMALS PROBABLY DUE TO SIMILAR CON-
DITIONS OF THE SOIL.

The modern study of the sanitary relations of the soil is
till in its infancy. Whatever definite knowledge has bee gained relates merely to physical or chemical conditions of the soil and its atmosphere and moisture, or possibly the relations of these to the spread of certain diseases in buman
beings. But there is, perhaps, a wider application that may be made of such knowledge than bas been heretofore sug
gested. The domestic animals which form such at large gested. The domestic animals which form such in large
proportion of the wealth of this country-horses, cattle,
sheep, and bogs-are liable to infectious and contagious diseases as well as buman beings, and many millions of
dollars are lost annually by the ravages of such diseases. Now, from what is known of such diseases as splenicferer
among cattle, and of the so-called sucine plague, it does not appear improbable to the writer that the source of infection
is a soil polluted by the poisonous germ of the diseases, just and possibly malarial fevers, are so caused. The laborious investigations of $M$. Pasteur in France bave shown that the cause of splenic fe ver when once introduced iuto a locality
will remain active for months and even years, and it does not seem out of place to suggest to the readers of this re-
port, most of whom are interested in the preservation of the pealth of the domestic animals, that a study of the soil in its which they may direct their attention with profit.
It is well known that milch cows frequently suffer from disease identical in its nature with the consumption in
buman beings. It is believed by many that the milk of such auimals is not only unfit for food by reason of its poor
quality, but that it may convey the disease to buman beings
when used as food. The observations of Bowditch and when used as food. The observations of Bowditch and
Bucbanan, quoted above, show that consumplion in man machanan, quoted above, show that consumption in maa
may be, and doubtless is, frequently caused hy soil wet ness It seems probable that the same cause sheuld producessmi-
lar effects in the lower animals, and it is the writer's firm conviction that an examination into the circumstances uncler wact.

\section{VI.-THE PREVENTIVE REMEDY-DRAINAGE.}

To secure a constant level of the ground water at a suffimany soils. Agriculturists know the value of proper and
mants and efficient drainage in improving the productive capacity of
wet soils, but the men who build houses for buman being to live in, or stables to shelter animals, never give this mat-
ter mucb thought. Few of our architects bave ever leard f the injunction of the ancient master of their craft, quoted in the beginning of this paper, to select a bealthy soil upon
which to build a dwelling, while a stable is frequently built
partly underground, and in localities where all the condimade to understand that a wet stable, whether for borses, cows, sheep, or bogs, is an unbealthy stable, reform would
soon be introduced. If they could be furtber convincer that a marshy or springy soil is not a bealtly pasture
ground, such places would soon be drained. If it were nimals was improved and their lives preserved, perbap architects and builders in town and country would also learn that a $d$ welling cannot be
unless built upon a clean, dry soil.

THE Boston Watchman says that within the last nine years nearly eight hundred churches have been hurned in
America. A church that will not burn seems to be a much 